$\xi=-1$

\title{
Perceived Consumption Values, Satisfaction and Loyalty in the Tourism: Case of Malaysia
}

\author{
Adeline Shu Wan, Tan $^{1}$, Mohammad Falahat ${ }^{2}$, Bik Kai Sia ${ }^{3} *$ \\ ${ }^{1,2,3}$ Universiti Tunku Abdul Rahman (UTAR), Malaysia. \\ *Corresponding author E-mail: siabk@utar.edu.my
}

\begin{abstract}
Domestic tourism is a substitute for outbound travel has a potential to create income and employment in the home economy. These potentials also create opportunities through the linkage at destinations. This study extent the concept and evaluates the empirical evidence of the relationship between perceived consumption values toward tourism loyalty. Drawn from revised framework of the Sheth-Newman Gross Model of Consumption Values and the European Consumer Satisfaction Index (ECSI), we examine the relationship of perceived consumption values, tourist satisfaction and tourist loyalty. Data obtained from 255 tourists visited the state of Malacca, Malaysia. The results indicated that tourist loyalty is affected by perceived consumption values and fully mediated by tourist satisfaction. The findings provide valuable insights to the policy makers, industries and academics in developing strategies and exploring possible factors to consider in tourism sector and thus, boost the national economy. As for policy makers, this study can be seen as exploitation to increase the influx of international tourists by implementing policies or improving tourist spots.
\end{abstract}

Keywords: ECSI model; Perceived Consumption Values; Tourist Loyalty; Tourist Satisfaction

\section{Introduction}

World Tourism Organization (1) reported the number of domestic tourists in 2011 is 162.8 millions who spent RM 42,346 million or RM 260 per trip. Most of domestic tourists (83.5\%) stay at their friends or relatives houses and 14.2 percent of them stay at hotels, while most of international tourist stay in the hotels, apartments or budget hotels (2). Nevertheless, domestic tourism is important because it acts as a substitute given the constraints on international and long-haul travel as well as the possible reductions in the money people have for spending or the time they need for travel (3) Domestic tourism as a substitute for outbound travel has a potential to create income and employment in the home economy. These potentials also create opportunities through the linkage at destinations. Besides that, domestic tourists serve as an essential source of operational revenue and proactive support such as positive word of mouth referrals (4). Hence, tourism marketers need to have a better understanding in tourists' loyalty among the perceived consumption values and tourists' satisfaction.

There are many research relating the model of consumption values to the consumer choice behavior or customer satisfaction. Besides that, there are also many researchers studying the European Customer Satisfaction Index (ECSI) model or the American Customer Satisfaction Index (ACSI) model relating to both variables of the tourist satisfaction and tourist loyalty. However, there is dearth of research on using both the ECSI model together with the commonly used model of consumption values to study the tourist satisfaction and tourist loyalty. Inspecting the relationship between the model of consumption values and the ECSI model to the tourists' satisfaction and tourists' loyalty would be an advantage for tourism destination marketers and stakeholders in efficaciously building a country brand.

\section{Problem Statement}

The basic ECSI model is an approach that computes a customer satisfaction index using structural equation model (SEM) with observable dormant variables which differ from the ACSI model. The model is an adaption from the Swedish Customer Satisfaction Barometer (SCSB) model (Fornell, Johnson, Anderson, Cha, \& Bryant, 1996) which is compatible to the ACSI model. This model connects customer loyalty from customer satisfaction where it is the determinants and shift to its consequence. The model uses a structural equation modelling with the six dormant variables which aim to supply an accurate and comprehensive description of the processes underlying customer satisfaction and customer loyalty. The determinants of customer satisfaction are customer expectations, destination image, perceived quality and perceived value regarding the value of money.

(Johnson, Gustafsson, Andreassen, Lervik, \& Cha, 2001) maintained that both the ECSI and ACSI models have its significant difference. The prevalence of complaint behaviour is the consequence of satisfaction but it is not included in the ECSI model. However, the ACSI model does include this incidence which is the result of satisfaction. Therefore, the adoption of this ECSI model is suitable to be combining with the model of consumption values. The baseline to this study is therefore by using the wellknown customer satisfaction index called the ECSI model as stated. Besides that, there are researchers in different countries have studied domestic tourism with similar outcomes. These studies state that the need to understand the preferences of tourists and highlighted the distinction in the tourists' preferences towards varied destinations. Moreover, the influence of destination and household characteristics on the decision-making process of tourists was also analysed (Bargeman \& van der Poel, 2006). 
The conditional value which is the only variable that is adapted from the model of consumption values. It will influence a choice maker to either change his or her purchasing plan (Sheth, Newman, $\&$ Gross, 1991). (Sheth et al., 1991) described conditional value as the perceived utility acquired through a secondary way where the result of the conditions faced by the choice maker. A subtitute acquires conditional value where the existence of social or physical contingencies that improve its functional or social value. (Williams \& Soutar, 2000) stated that conditional value shows a positive effect in the tourists decision-making in the tourism context can be exceptional events in a country. Moreover, (Tapachai \& Waryszak, 2000) states ease of access to another country, proximity and relative cheapness of travel are the factor of conditional value where it shows a positive relationship. Therefore, we propose the below hypothesis:

Hypothesis $1(\mathrm{H} 1)$ : There is a positive correlation between the conditional value and perceived consumption value.

Various authors have studied destination image. (Crompton \& Ankomah, 1993) stated that destinations image gives positive image in the process of decision making. It also gives positive influences on perceived quality and satisfaction (Ross, 1993) Moreover, destination experience or destination image was evaluated to influence to a higher tourist satisfaction (Echtner \& Ritchie, 2003). Lastly, (Court \& Lupton, 1997) stated that destination image gives positive effects on tourist loyalty or intention to revisit Hence, the hypothesis that is developed is:

Hypothesis 2 (H2): There is a positive relationship between the destination image and perceived consumption value.

Perceived quality of hardware and humanware are another variables of perceived consumption values in tourism research. A few studies are suggesting that perceived quality of hardware and humanware are related to perceived consumption values. The reason is perceived quality of hardware and humanware are related to long term cognitive evaluations but tourist satisfaction is related to short-term evaluations (Oliver, 2014; Rust \& Oliver, 2000; Taylor \& Baker, 1994; Tian-Cole, Crompton, \& Willson, 2002). Other studies reported that perceived quality of hardware and humanware indirectly affect tourist loyalty through tourist satisfaction ( Chen, 2008; Chen \& Tsai, 2007). (Baker \& Crompton, 2000) reporting that there is a positive relationship between these two variables and (X. Wang, Zhang, Gu, \& Zhen, 2009) confirmed it through their investigation. However, there are a few studies reported that perceived quality of hardware has a negative relationship to perceived consumption value (Brown \& Mazzarol, 2009; O'Loughlin \& Coenders, 2002).

Hypothesis $3(\mathrm{H} 3)$ : There is a positive correlation between the perceived quality of hardware and perceived consumption value. Hypothesis $4(\mathrm{H} 4)$ : There is a positive correlation between the perceived quality of humanware and perceived consumption value. Tourist expectation is a key element of tourist satisfaction (Oliver, 2014). Service delivered and money paid is also known as perceived value where it can be the basis for assessment. (Demirovic \& Njegovan, 2014) stated that the study of tourist expectation has a significant impact in the service sector. Besides that, (Lather, Singh, \& Singh, 2012) also indicated that the level of expectation and satisfaction in the study of the tourism industry has a significant effect in a given destination. However, researchers are arguing that tourist expectation is formed before they consume it (Akama \& Kieti, 2003). On the other hand, (del Bosque, San Martín, \& Collado, 2006) suggested that tourist expectations resulted from experience. In fact, there are many experts studied that tourist expectation has a direct effect on perceived value and tourist satisfaction (Song, van der Veen, Li, \& Chen, 2012). Therefore, the hypothesis formulated in this study is:

Hypothesis 5 (H5): There is a positive relationship between the tourist expectation on perceived consumption value.

Perceived consumption value may also be affected by the perceived quality and tourist expectation (Bayol, de la Foye, Tellier, \& Tenenhaus, 2000). Alternatively, (Hur, Kim, \& Park, 2013) debated that customer satisfaction is interlinked with customer loyalty by lowering price consciousness. Nonetheless, many other researchers view latter behaviour could be the consequences of customer loyalty (Dick \& Basu, 1994; Juščius, Navickas, \& Jonikas, 2017). Customer perceived value outcomes from an evaluation of the related sacrifices and rewards related with the offerings. Furthermore according to ( Wang, Li, Chou, \& Huang, 2014), perceived value is a crucial aspect to the satisfaction level. Both the concepts of perceived value and satisfaction are almost similar and easily mixed-up when explained. Hence, two hypotheses were formulated as stated:

Hypothesis 6 (H6): There is a positive relationship between perceived consumption value and tourists' satisfaction.

Hypothesis 7 (H7): There is a positive relationship between perceived consumption value and tourists' loyalty.

The customer loyalty or tourist loyalty definition was originally developed by the ECSI model which is a useful framework till today. (Zeithaml, Berry, \& Parasuraman, 1996) report that satisfaction is an antecedent of repetitive purchase and post-purchase attitudes. Most researchers agree that satisfaction affects loyalty (Cronin, Brady, \& Hult, 2000). The results of the previous research show a significant direct positive effect on tourist satisfaction on tourist loyalty (Choi \& Chu, 2001; Szymanski \& Henard, 2001). On the other hand on the business view, satisfaction and loyalty go along together well in a long term period (Nicholls, Gilbert, \& Roslow, 1998). In tourism context, tourist satisfaction is positively related to tourist loyalty (Bowen \& Chen, 2001; Petrick, Morais, \& Norman, 2001; Sönmez \& Graefe, 1998). It can also be seen in a recent study that confirms tourist satisfaction from tourist experience shows a positive relationship to loyalty (Alexandris, Kouthouris, \& Meligdis, 2006; Chi \& Qu, 2008). (Niininen, Szivas, \& Riley, 2004) imply that satisfaction and loyalty are not positively related. Hence, a few studies are emphasizing in detail the relationship between satisfaction and loyalty (Bennett \& Rundle-Thiele, 2004). However, in the marketing point of view, tourist loyalty is the result of tourist satisfaction where it can be seen in several studies (Mattila, 2001). Therefore, we finally hypothesise that:

Hypothesis $8(\mathrm{H} 8)$ : There is a positive relationship between tourists' satisfaction, and tourists' loyalty.

As mention in previous studies, in the biggest part of customer satisfaction research methodologies especially in the European Customer Satisfaction index, the major consequence of satisfaction is seen to be loyalty to the destination. Subsequently, the mediating relationship in the model where tourist satisfaction was introduced as a mediator between perceived consumption value and tourist loyalty (Osman \& Sentosa, 2013). Furthermore, (Chi \& $\mathrm{Qu}, 2008$ ) stated that satisfaction plays a major role in being the mediating role in behavioural model. Thus, a hypothesis was formulated:

Hypothesis 9 (H9): Tourist satisfaction mediates the relationship between perceived consumption value and tourist loyalty. The conceptual model of the study is depicted as Figure 1.

\section{Research Questions}

This study or research is attempted to analyze the structural relationship of perceived consumption values, tourists' satisfaction and tourists' loyalty based on the revised framework of the model of consumption values and the ECSI model to be more comprehensive to understand and provide new direction to applied research and academic.

\section{Purpose of the Study}

The objectives of this study are to develop an appropriate customer satisfaction index model and identify any significant relationship between guests' perceptions of destination image, tourist expectation, hardware, humanware, conditional value, and per- 
ceived consumption value. The study also intends to explore the relationship among perceived consumption value, tourist satisfaction and tourist loyalty.

\section{Research Methods}

The targeted sample in this study is the Malaysian aged 21 years and above with at least one local tourism experience. The study was conducted in the Malacca, one of the UNESCO World Heritage Site in Malaysia and the data were collected through a selfadministrative questionnaire from January 2015 until February 2015. The total number of completed questionnaires comprises 255 Malaysian tourists.

\subsection{Measures}

The questionnaire was drafted based on some previous studies on this topic (5-7). The draft questionnaire was pretested and modified before the final survey. The questionnaire was designed to collect demographic information and the perception of domestic tourists on the destination image, hardware as well as humanware, their expectation, conditional value, perceived consumption value, satisfaction and loyalty. In the questionnaire, all the constructs were measured on a scale 1 to 5 where 5 indicates the highest level of agreement. These constructs were coded respectively where the destination image (DI), tourist expectation (TE), perceived quality of hardware (HAR), perceived quality of humanware (HUM), conditional value (CV), perceived consumption value (PCV), tourist satisfaction (TS) and tourist loyalty (TL). The data were analyzed using the computer software with graphical user interface for variance-based partial least squares structural equation modeling (PLS-SEM) using the Smart Partial Least Squares interface (SmartPLS).

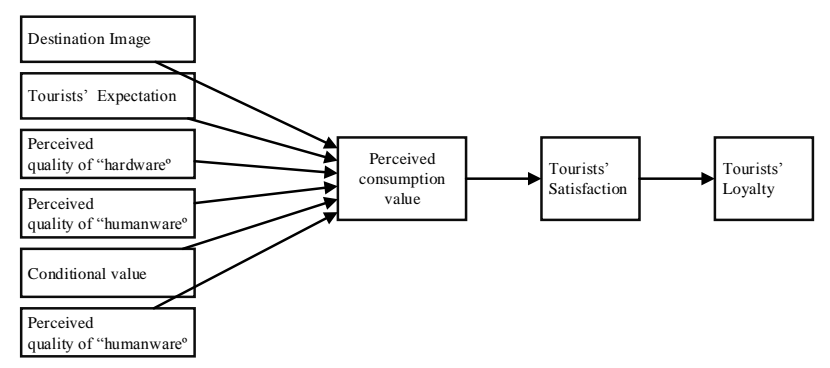

Fig. 1: Conceptual model

\section{Findings}

\subsection{Characteristics of Respondents}

The tourists visited Malacca resulted to male (54\%) and female (46\%). Many visitors who visited Malacca were young adults at age of $21-30(75 \%)$ and the minority visitors were ranging at the age of 31-40 (10\%), and more than $40(15 \%)$ in age. Besides that all three main races visited Malacca before however, Chinese (75\%) showed the most significant number as compare to Malay $(23 \%)$ and Indian $(3 \%)$. Nearly a third of the respondents were married (28\%), and divorced (2\%). The remaining were single (71\%) respondents.

Tourists who responded to the survey stayed in Malacca for two nights $(27.1 \%)$ and three nights $(15.70 \%)$ were approximately similar (Table 1). Approximately $53 \%$ of the visitors stayed one night. Besides, there were only a mere $3 \%$ of visitors who stayed for 4 nights. The visitors presented six purposes of visiting here including business and professional (6.7\%), leisure/vacation/recreation/holiday $(79.2 \%)$, visiting friends, visiting relatives, health treatment and family reunion (18.8\%). For the category of planning to spend for this trip in Malacca, most re- spondents planned to spend at about RM500 spending (54.10\%). At the range of RM500 to RM999 (17.6\%) and the range of RM1,000 to RM1,999 (28.3\%) were stated in Table 1. For the "plan to spend for this trip in Malaysia" category, the majority of respondents spend less than RM500 (43.9\%). Respondents spend from RM500 to RM999 (20.40\%), RM1,000 to RM1,999 (12.5\%) and RM2,000 and above (23.3\%) were slightly higher as compare to the remaining spenders. The sample represented the perceptions of tourists who are visiting this place.

\subsection{Characteristics of Respondents}

This section portrays the analysis using the SmartPLS to show the confirmatory factor analysis (CFA). Table 2 shows the measurement model with reflective indicators was evaluated through many range of analysis to examine the reliability of each items, construct reliability, discriminant reliability and average variance extracted analysis (Ricther et al, 2016). A measurement model was tabulated which satisfy the internal consistency reliability when each items exceeds the threshold value of 0.7 in the composite reliability (CR). The indicator consistency is calculated through the items loading as seen in Table 3. It is determined that the satisfactory indicator consistency is when the value loading of each item will be at least of 0.7 . All the items as seen based on the analysis in the measurement model exceed more than 0.7, ranging from lower bound (0.71) to upper bound (0.90). Table 2 exhibits that each loading for the item has shown satisfactory indicator reliability based on the analysis. Besides that, the convergent validity is measured where the average variance extracted (AVE) value is more than 0.5 as seen in Table 2 .

Table 1: Personal Information of the Sample.

\begin{tabular}{|c|c|c|}
\hline Personal Information & Frequency & Percentage \\
\hline \multicolumn{3}{|l|}{ Gender } \\
\hline Male & 137 & 53.7 \\
\hline Female & 118 & 46.3 \\
\hline \multicolumn{3}{|l|}{ Age } \\
\hline $21-30$ & 191 & 74.9 \\
\hline $31-40$ & 25 & 9.8 \\
\hline$>40$ & 39 & 15.3 \\
\hline \multicolumn{3}{|l|}{ Race } \\
\hline Chinese & 190 & 74.5 \\
\hline Malay and Indian & 65 & 25.4 \\
\hline \multicolumn{3}{|l|}{ Marital status } \\
\hline Single & 181 & 71.0 \\
\hline Married & 70 & 27.5 \\
\hline Divorced & 4 & 1.6 \\
\hline \multicolumn{3}{|l|}{ Nights of Stay } \\
\hline 1 & 137 & 53.7 \\
\hline 2 & 69 & 27.1 \\
\hline $3+$ & 48 & 18.8 \\
\hline \multicolumn{3}{|l|}{ Main Purpose of Visit } \\
\hline Business \& Professional & 17 & 6.7 \\
\hline Leisure/Vacation/Recreation/Holiday & 202 & 79.2 \\
\hline Visiting Friends/Relatives & 48 & 18.8 \\
\hline \multicolumn{3}{|l|}{ Plan to spend for this trip in MALACCA } \\
\hline Below RM500 & 138 & 54.1 \\
\hline RM500 - RM999 & 45 & 17.6 \\
\hline RM $1,000 \&$ above & 72 & 28.3 \\
\hline \multicolumn{3}{|l|}{ Plan to spend for this trip in MALAYSIA } \\
\hline Below RM500 & 112 & 43.9 \\
\hline RM500 - RM999 & 52 & 20.4 \\
\hline RM 1,000 - RM 1,999 & 32 & 12.5 \\
\hline RM 2,000 \& above & 59 & 23.3 \\
\hline
\end{tabular}
Note: RM1 = US $\$ 4.45$ 
Table 2: Measurement Model.

\begin{tabular}{|c|c|c|c|c|c|}
\hline Construct & Items & & Loadings & AVE & $\mathbf{C R}$ \\
\hline \multirow[t]{6}{*}{ Destination Image } & DI 1 & Malacca has a unique image. & 0.80 & 0.60 & 0.90 \\
\hline & DI 2 & This tourist destination (Malacca) has a historical image. & 0.81 & & \\
\hline & DI 3 & I think Malacca is well-known. & 0.79 & & \\
\hline & DI 4 & There are many historical monuments in Malacca. & 0.80 & & \\
\hline & DI 5 & There are many local traditional handcrafts. & 0.72 & & \\
\hline & DI 6 & There are museums in Malacca. & 0.72 & & \\
\hline \multirow[t]{3}{*}{ Tourist Expectation } & TE 1 & I am pleased that I decided to visit Malacca. & 0.86 & 0.64 & 0.84 \\
\hline & TE 2 & I will speak highly of Malacca to my friends and colleagues. & 0.79 & & \\
\hline & TE 3 & The visit to this tourist destination exceeded my expectations. & 0.74 & & \\
\hline \multirow[t]{3}{*}{ PQ Hardware } & HAR 1 & Knowledge of attractions and activities by hotel staff. & 0.81 & 0.67 & 0.89 \\
\hline & HAR 2 & Quality of the information services. & 0.84 & & \\
\hline & HAR 3 & Professionalism tour services. & 0.89 & & \\
\hline \multirow[t]{3}{*}{ PQ Humanware } & HUM 1 & Helpfulness of the local people & 0.90 & 0.72 & 0.89 \\
\hline & HUM 2 & Friendliness of the local people. & 0.89 & & \\
\hline & HUM 3 & Good service of the accommodation & 0.75 & & \\
\hline \multirow[t]{7}{*}{ Conditional Value } & CV 1 & Available vacation time & 0.70 & 0.57 & 0.90 \\
\hline & $\mathrm{CV} 2$ & Travel time to destination (e.g. from the hotel to travel spot) & 0.75 & & \\
\hline & CV 3 & Interesting activities at destination & 0.78 & & \\
\hline & $\mathrm{CV} 4$ & Getting right person to travel together & 0.78 & & \\
\hline & CV 5 & $\begin{array}{l}\text { The difference preferences/interests of family and/or friends } \\
\text { in this trip }\end{array}$ & 0.77 & & \\
\hline & CV 6 & Amount of travel information & 0.75 & & \\
\hline & CV 7 & Own personal health/physical condition & 0.74 & & \\
\hline \multirow[t]{4}{*}{$\begin{array}{c}\text { Perceived consump- } \\
\text { tion value }\end{array}$} & PCV 1 & All things considered, this is my best choice. & 0.85 & 0.63 & 0.89 \\
\hline & PCV 3 & My wants and needs will be fulfilled by this visit. & 0.79 & & \\
\hline & PCV 4 & The service at this location is good for the price I paid. & 0.79 & & \\
\hline & PCV 5 & $\begin{array}{l}\text { My total expenditures are reasonable for the service I re- } \\
\text { ceived. }\end{array}$ & 0.72 & & \\
\hline \multirow[t]{3}{*}{ Tourist Satisfaction } & TS 1 & My decision is thorough when choosing this place. & 0.81 & 0.78 & 0.92 \\
\hline & TS 2 & I am satisfied with my decision to travel to this place. & 0.85 & & \\
\hline & TS 3 & $\begin{array}{l}\text { I think I did the right thing when I chose to travel to this } \\
\text { place. }\end{array}$ & 0.88 & & \\
\hline \multirow[t]{4}{*}{ Tourist Loyalty } & TL 1 & I will recommend this place to friends or other persons. & 0.86 & 0.70 & 0.90 \\
\hline & TL 2 & I will say positive things about this place to my friends. & 0.84 & & \\
\hline & TL 3 & I will encourage friends to travel to this place. & 0.89 & & \\
\hline & TL 4 & I will intent to visit this place again. & 0.77 & & \\
\hline
\end{tabular}

Note. $\mathrm{AVE}=$ average variance extracted $\mathrm{CR}=$ composite reliability

\subsection{Discriminant Validity}

In the study, the adaptation from Fornell and Larcker (1981) criterion is being used to assess the measurement model's discriminant validity. A measurement model has discriminant validity where the square root of AVE exceeds the correlations between the measure and all other measures. The AVE value is generated by using the SmartPLS algorithm function where it is used to assess the first assessment of the measurement model's discriminant validity. The entire square root is the AVE should exceed the offdiagonal elements in the rows and column specifically based on the results. As seen in Table 3, all the off-diagonal elements are lesser than the square roots of the AVE (bold in the table). Therefore, the Fornell and Larcker's condition results is met and sustained.
As a result, the reliability and validity tests conducted on the measurement model are satisfactory. These confirmed that all the indicators from the measurement model of this study based on the reliability and validity tests are fit and valid.

\subsection{Structural Model}

The relationships between the five constrcts to percevied consumption values show an R2 of 0.47 indicating that $47.3 \%$ of the variance in perceived consumption value as seen in Figure 2. Perceived consumption value to tourist satisfaction $(\beta=0.78, \mathrm{p}<.01)$ was positively related to tourist satisfaction with an $\mathrm{R} 2$ of 0.528 indicating that this particular construct explains $52.8 \%$ of the variance in the tourist satisfaction. Therefore, H6 is supported. Moreover, perceived consumption value to tourist loyalty 
$(\beta=0.63, \mathrm{p}<.01)$ was also positively related to tourist loyalty. Thus, $\mathrm{H} 7$ is also supported. Lastly, tourist satisfaction to tourist loyalty $(\beta=0.57, p<.01)$ was also positively related to tourist loyalty with an R2 of 0.606 indicating that the tourist satisfaction construct explains $60.6 \%$ of the variance in the tourist loyalty. Thus, $\mathrm{H} 8$ is also supported. These results can be seen in Table 4. In conclusion, the above values signify that the framework has sufficient level of reliability and validity in this study.

Table 3: Discriminant Validity.

\begin{tabular}{|c|c|c|c|c|c|c|c|c|}
\hline & 1 & 2 & 3 & 4 & 5 & 6 & 7 & 8 \\
\hline 1. Conditional Value & 0.74 & & & & & & & \\
\hline 2. Destination Image & 0.26 & 0.78 & & & & & & \\
\hline 3. Perceived Quality Hardware & 0.39 & 0.55 & 0.79 & & & & & \\
\hline 4. Perceived Quality Humanware & 0.28 & 0.50 & 0.41 & $\mathbf{0 . 8 2}$ & & & & \\
\hline 5. Perceived Consumption Value & 0.05 & 0.48 & 0.51 & 0.61 & 0.85 & & & \\
\hline 6. Tourist Expectation & 0.07 & 0.47 & 0.41 & 0.52 & 0.56 & $\mathbf{0 . 8 0}$ & & \\
\hline 7. Tourist Loyalty & 0.09 & 0.56 & 0.63 & 0.41 & 0.54 & 0.47 & 0.84 & \\
\hline
\end{tabular}

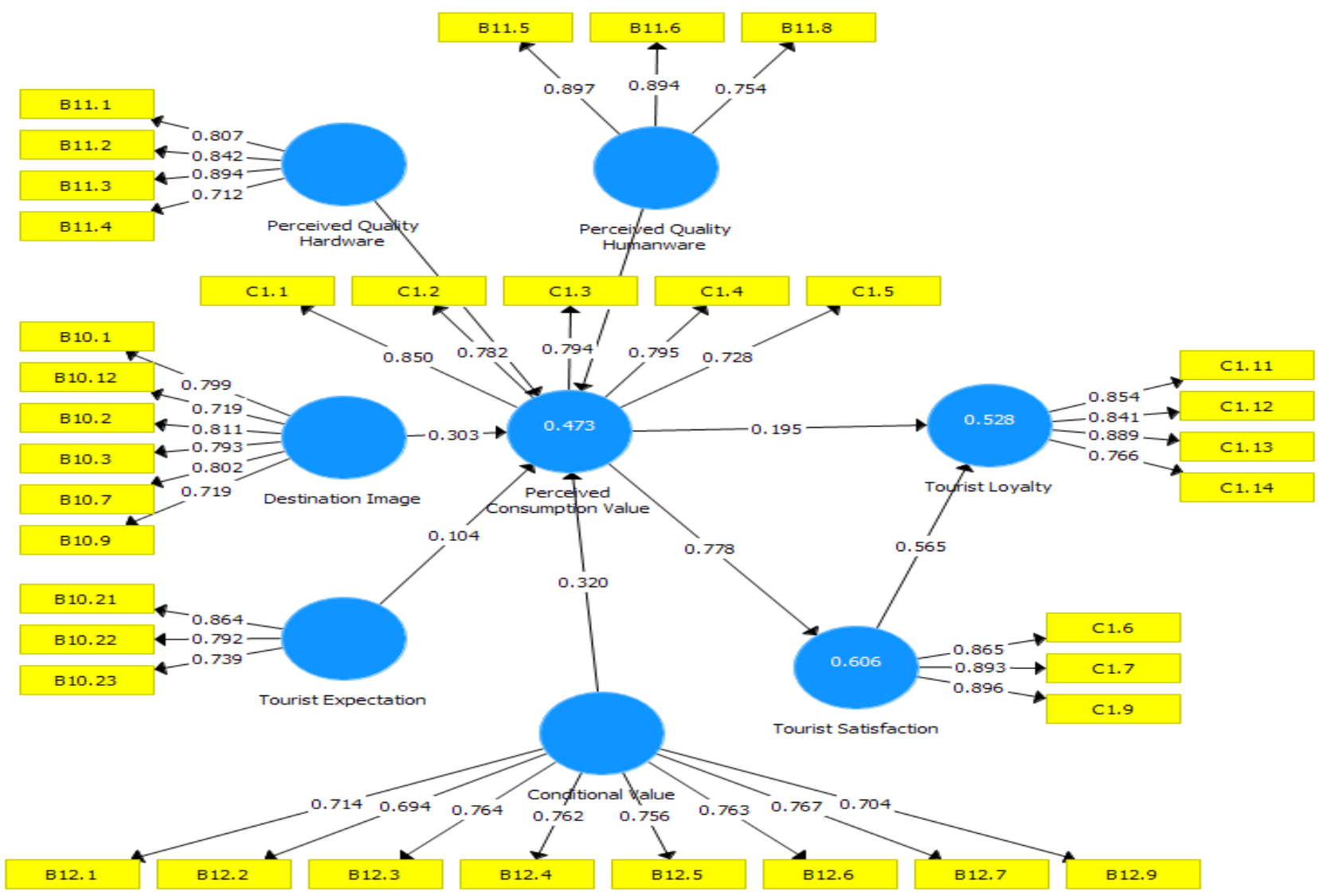

Fig. 2: Results of the Path Analysis.

Table 4: Hypothesis Testing

\begin{tabular}{|c|c|c|c|c|c|c|c|c|}
\hline Hypothesis & Relationship & Standardized & SE & $\begin{array}{c}t- \\
\text { value }\end{array}$ & $\begin{array}{c}\text { Deci- } \\
\text { sion }\end{array}$ & $\overline{\mathbf{R}^{2}}$ & $\mathrm{~F}^{2}$ & $\mathbf{Q}^{2}$ \\
\hline Hypothesis 1 & $\begin{array}{l}\text { DESTINATION IMAGE } \rightarrow \text { PERCEIVED } \\
\text { CONSUMPTION VALUE }\end{array}$ & 0.30 & 0.05 & $\begin{array}{l}6.26^{*} \\
*\end{array}$ & Support & - & 0.12 & - \\
\hline Hypothesis 2 & $\begin{array}{l}\text { TOURIST EXPECTATION } \rightarrow \text { PERCEIVED } \\
\text { CONSUMPTION VALUE }\end{array}$ & 0.10 & 0.09 & 1.20 & Not Support & - & 0.01 & - \\
\hline Hypothesis 3 & $\begin{array}{l}\text { PERCEIVED QUALTIY HARDWARE } \rightarrow \\
\text { PERCEIVED CONSUMPTION VALUE }\end{array}$ & -0.11 & 0.06 & 1.82 & Not Support & - & 0.01 & - \\
\hline Hypothesis 4 & 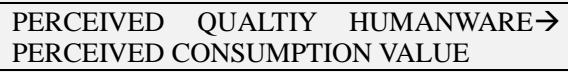 & 0.36 & 0.06 & $\begin{array}{ll}6.43^{*} \\
*\end{array}$ & Support & - & 0.12 & - \\
\hline Hypothesis 5 & $\begin{array}{l}\text { CONDITIONAL VALUE } \rightarrow \\
\text { CONSUMPTION VALUE }\end{array}$ & 0.32 & 0.05 & $\begin{array}{ll}6.25^{*} \\
*\end{array}$ & Support & - & 0.17 & - \\
\hline Hypothesis 6 & $\begin{array}{l}\text { PERCEIVED CONSUMPTION VALUE } \rightarrow \\
\text { TOURIST SATISFACTION }\end{array}$ & 0.78 & 0.03 & $\begin{array}{ll}24.03 \\
* *\end{array}$ & Support & 0.47 & 1.54 & 0.45 \\
\hline Hypothesis 7 & $\begin{array}{l}\text { PERCEIVED CONSUMPTION VALUE } \rightarrow \\
\text { TOURIST LOYALTY }\end{array}$ & 0.63 & 0.05 & $\begin{array}{l}12.66 \\
* *\end{array}$ & Support & 0.53 & 0.03 & 0.28 \\
\hline Hypothesis 8 & $\begin{array}{llll}\begin{array}{l}\text { TOURIST } \\
\text { LOYALTY }\end{array} & \text { SATISFACTION } & \rightarrow & \text { TOURIST } \\
\end{array}$ & 0.57 & 0.08 & $\begin{array}{l}7.04 * \\
*\end{array}$ & Support & 0.61 & 0.27 & 0.38 \\
\hline
\end{tabular}


Table 5: Mediation Analysis

\begin{tabular}{|c|c|c|c|c|c|c|c|c|}
\hline Hypothesis & \multicolumn{2}{|c|}{ Description } & Standardized $\beta$ & SE & $t$-value & Decision & VAF & Type of \\
\hline \multirow[t]{2}{*}{ Hypothesis 9} & $\begin{array}{l}\text { Indirect } \\
\text { Effect }\end{array}$ & Perceived Consumption Value $\rightarrow$ Tourist Loyalty & 0.44 & 0.06 & 7.09 & $\begin{array}{c}\text { Not } \\
\text { Support }\end{array}$ & $12.40 \%$ & \\
\hline & $\begin{array}{l}\text { Total } \\
\text { Effect }\end{array}$ & Perceived Consumption Value $\rightarrow$ Tourist Loyalty & 0.63 & 0.05 & 12.66 & Support & $87.60 \%$ & $\begin{array}{l}\text { Full Media- } \\
\text { tion }\end{array}$ \\
\hline
\end{tabular}

Lastly, the mediation test was assessed as seen in Table 6. The variance accounted for (VAF) of perceived consumption value to tourist loyalty was $12.40 \%$. It can be calculated by dividing the standard error of the indirect effect of the standard error of the direct effect. Thus, tourist satisfaction mediates the relationship between perceived consumption value and tourist loyalty. The VAF indicates that $87.60 \%$ of the effect of tourist satisfaction on tourist loyalty is explained by the perceived consumption value mediator (full mediation). Thus, H9 is supported.

\section{Conclusion}

The result of this study showed sufficient empirical evidence to support the relationship between perceived consumption values, tourist satisfaction, and tourist loyalty. Although the literature review has given much attention to factors affecting these variables, few studies are stating there is a mediation relationship between these three variables $(8,9)$. Hence, this study can provide significant implications for policy makers and tourism marketers. The first finding of this study is that visitors of Malaysia in the region of Malacca stated three reasons for travelling or visiting were because of the destination image, the perceived quality of humanware and their constraints which is in line with previous studies (10-12). The results of the study provide information to tourism marketers who should consider these reasons, as they could be the major factors for increasing loyalty with the services offered. Therefore, they should pay extra attention to tourist visiting local historical sites, visiting historic culture and the uniqueness of the destination. (13) found similar results that domestic tourists usually visit historical and cultural heritage destination and give lesser importance to material aspects. It is found that these places give consideration to comfort, convenience and affordability of travel and stay, as well as to the sightseeing and shopping opportunities.

The next finding of this study consists of the expectation and services they received that should be expected are the knowledge, quality, and professionalism of tour services and information counter. Besides that, the friendliness, good services and helpfulness of locals are also the services received and expected are good. Hence, again these results can lead tourism marketers about what angle should be focussed in their offer. In this case, a suitable range of sight-seeing spots is one of the assets that tourism marketers can make the destination attractive and more competitive. The first finding suggests that destination image, perceived quality of humaware and conditional value have significant extent on the level of perceived consumption value. Hence, with the positive relationship of perceived consumption values with the three variables confirms that perceived consumption value is association to tourist satisfaction and tourist loyalty but with a much lesser significant relationship. Thus, this relationship can be explained that tourist satisfaction is the mediating variable between perceived consumption values and tourist loyalty. To retain or increase the level of tourist loyalty, tourism marketers should consider tourist satisfaction as a dominant contribution where the previous study also stated as well (14).

In conclusion, this study analyses the causal relationship of tourist loyalty and reveals the relationship of tourist satisfaction as a mediating variable. Analysis of the suggested relationships helps tourism marketers to specify their services and to know the factors why tourists traveled. As for policy makers, this study can be seen as exploitation to increase the influx of international tourists by implementing policies or improving tourist spots. Analytically, the results attain are not free of limitations, as it was taken from a specific location at a specific time of year. Further research is needed in this direction to understand how tourist loyalty with a different destination at a different time of year can be achieved.

\section{References}

[1] Kester JG. 2012 International Tourism Results and Prospects for 2013. United Nations World Tourism Organization (UNWTO), Madrid. 2013.

[2] Chen I-T, Weicht KK. Tourism Development and Rural Tourism in Taiwan. Tourism and Opportunities for Economic Development in Asia. 2017:203.

[3] Sheldon P, Dwyer L. The global financial crisis and tourism: Perspectives of the academy. Journal of Travel Research. 2010;49(1):3-4.

[4] Kwenye JM, Freimund W. Domestic tourists' loyalty to a local natural tourist setting: Examining predictors from relational and transactional perspectives using a Zambian context. Tourism Management Perspectives. 2016;20:161-73.

[5] Fornell C, Johnson MD, Anderson EW, Cha J, Bryant BE. The American customer satisfaction index: nature, purpose, and findings. the Journal of Marketing. 1996:7-18.

[6] Gallarza MG, Saura IG. Value dimensions, perceived value, satisfaction and loyalty: an investigation of university students' travel behaviour. Tourism management. 2006;27(3):437-52

[7] Srisutto S. Country branding, consumption values, and purchase decision confidence: a case study of tourists to Thailand: Lincoln University; 2010.

[8] Chi CG-Q, Qu H. Examining the structural relationships of destination image, tourist satisfaction and destination loyalty: An integrated approach. Tourism management. 2008;29(4):624-36.

[9] Osman Z, Sentosa I. Mediating effect of customer satisfaction on service quality and customer loyalty relationship in Malaysian rural tourism. 2013.

[10] Court B, Lupton RA. Customer portfolio development: Modeling destination adopters, inactives, and rejecters. Journal of Travel Research. 1997;36(1):35-43.

[11] Crompton JL, Ankomah PK. Choice set propositions in destination decisions. Annals of Tourism Research. 1993;20(3):461-76.

[12] Echtner CM, Ritchie J. The meaning and measurement of destination image:[Reprint of original article published in v. 2, no. 2, 1991: 2-12.]. Journal of tourism studies. 2003;14(1):37.

[13] Madhavan H, Rastogi R. Social and psychological factors influencing destination preferences of domestic tourists in India. Leisure Studies. 2013;32(2):207-17.

[14] Pilelienè L, Grigaliūnaitè V. Interaction between satisfaction and loyalty of Lithuanian rural tourists: a moderating effect of perceived value. Management Theory and Studies for Rural Business and Infrastructure Development. 2014;36(4):927-36. 